\title{
Table of international cases, treaties and other international instruments
}

\section{International Cases}

Advisory Opinion on the Legality of the Threat or Use of Nuclear Weapons, opinion of 8 July 1996 (ICJ Reports 1996, 226)

Case Concerning Gabčíkovo-Nagymaros Project (Hungaryv. Slovakia), decision of 25 September 1997 (ICJ Reports 1997, 7)

Case Concerning Pulp Mills on the River Uruguay (Argentina v. Uruguay), Judgment of 20 April 2010 $8,32,119,273$

Case Concerning Whaling in the Antarctic (Australia v. Japan: New Zealand intervening), Judgment of 31 March 2014

\section{International Treaties and Other International Instruments}

1948 Universal Declaration of Human Rights (1948) GA res. 217A (III), UN Doc $\mathrm{A} / 810$ at 71

1969 Convention on the Law of Treaties (Vienna, 23 May 1969) 1155 UNTS 331, in force 27 January 1980

1971 Convention on Wetlands of International Importance, especially as Waterfowl Habitat (Ramsar, 2 February 1971), 11 ILM 963, in force 21 December 1975

1972 Stockholm Declaration 11 ILM 1416 (1972) 16,108 Convention Concerning the Protection of the World Cultural and Natural Heritage (Paris, 16 November 1972) 1037 UNTS 151, in force 17 December 1975

1973 Convention on International Trade in Endangered Species of Wild Fauna and Flora (Washington DC, 3 March 1973), 993 UNTS 243, in force 1 July 1975

1974 Nordic Environmental Protection Convention (Stockholm, 19 February 1974), UNE EPL, Vol 1, 1975-1976 p 44, in force 5 October 1976 108

1979 Convention on the Conservation of Migratory Species of Wild Animals (Bonn, 23 June 1979), 19 ILM 15, in force 1 November 1983

Convention on Long-range Transboundary Air Pollution (Geneva, 13

November 1979), 1302 UNTS 217, in force 16 March 1983 ....4, 32, 171, 201,

1982 United Nations Convention on the Law of the Sea (Montego Bay, 10 
1984 Protocol on Long-term Financing of the Cooperative Programme for Monitoring and Evaluation of the Long-range Transmission of Air Pollutants in Europe (Geneva, 28 September 1984) 1491 UNTS 167, in force 28 January 1988 201

1985 Convention for the Protection of the Ozone Layer (Vienna, 22 March 1985), 1513 UNTS 323, in force 22 August 1988

Protocol on the Reduction of Sulphur Emissions or their Transboundary Fluxes by at least 30 Per Cent (Helsinki, 8 July 1985) 1480 UNTS 215, in force 2 September 1987 Association of South East Asian Nations, Agreement on the Conservation of Nature and Natural Resources, opened for signature 9 July 1985, 15 EPL 64 (1985), not in force $.28,302$

1987 Protocol on Substances that Deplete the Ozone Layer (Montreal, 16 August 1987), 1522 UNTS 3, in force 1 January 1989 $.28,222$

1988 Protocol on the Control of Emissions of Nitrogen Oxides or their Transboundary Fluxes (Sofia, 31 October 1988) 1593 UNTS 287, in force 14 February 1991

1989 Convention on the Control of Transboundary Movements of Hazardous Wastes and their Disposal (Basel, 22 March 1989), 28 ILM 657, in force 5 May 1992

Conference on Security and Cooperation in Europe, Concluding Document of the Vienna Meeting 1986 of Representatives of the Participating States of the Conference on Security and Co-operation in Europe, Vienna, 1989 ......16

1991 Convention on Environmental Impact Assessment in a Transboundary Context (Espoo, 25 February 1991), 30 ILM (1991) 802, in force 27 June 1997 $.4,36,59,105,171,242,300$

Protocol on the Control of Emissions of Volatile Organic Compounds or their Transboundary Fluxes (Geneva, 18 November 1991) 2001 UNTS 187, in force 29 September 1997

1992 United Nations Declaration on Environment and Development, Rio de Janiero, 1992. UN Doc A/CONF.151/5/Rev.1 (1992)

Convention on the Transboundary Effects of Industrial Accidents (Helsinki, 17 March 1992), 2105 UNTS 457, in force 19 April 2000 .....4, 106, 137, 168, 257

Convention on the Protection and Use of Transboundary Watercourses and Lakes (Helsinki, 17 March 1992), 31 ILM (1992) 1312, in force 6 October 1996 $4,43,137,167,246,305$

United Nations Framework Convention on Climate Change (Rio de Janiero, 9 May 1992), 1771 UNTS 107, in force 21 March 1994

Convention on Biological Diversity (Rio de Janiero, 22 May 1992), 31 ILM 822 , in force 29 December 1993 $27,214,300$ Agreement on Cooperation in the Field of Joint Management and Conservation of Interstate Water Resources (Almaty, 18 February 1992) accessed 20 November 2014 at http://www.caee.utexas.edu/prof/mckinney/ papers/aral/agreements/ICWC-Feb18-1992.pdf

1994 Protocol on Further Reduction of Sulphur Emissions (Oslo, 14 June 1994) 2030 UNTS 122, in force 5 August 1998 
Table of international cases, treaties \& other international instruments xiii

1995 Agreement on the Cooperation for the Sustainable Development of the Mekong River Basin (Chiang Rai, 5 April 1995), unreported, in force 5 April 1995

Agreement on the Establishment of the Tumen River Area Development Coordination Committee (New York, 6 December 1995), unreported, in force 6 December 1995 $.9,28,302$ Agreement on the Establishment of the Consultative Commission for the Development of the Tumen River Economic Development Area and Northeast Asia (New York, 6 December 1995), unreported, in force 6 December 1995 $9,28,302$

1997 Convention on the Law of Non-Navigable Uses of International Watercourses (New York, 21 May 1997, by UNGA Res. 51/229), 36 ILM (1997) 700, in force August 2014 $39,167,284,306$ Protocol to the United Nations Framework Convention on Climate Change (Kyoto, 11 December 1997), 37 ILM 22, in force 16 February 2005 28

1998 Protocol on Heavy Metals (Aarhus, 24 June 1998) 2237 UNTS 4, in force 29 December 2003 .202

Protocol on Persistent Organic Pollutants (Aarhus, 24 June 1998) 2230

UNTS 79, in force 23 October 2003 27,202

Convention on Access to Information, Public Participation in

Decision-Making and Access to Justice in Environmental Matters (Aarhus, 25 June 1998) 2161 UNTS 447, in force 30 October 2001 .......4, 59, 106, 171, 242,300

Convention on the Prior Informed Consent Procedure for Certain Hazardous Chemicals and Pesticides in International Trade (Rotterdam, 10 September 1998), 38 ILM 1, in force 24 February 2004

1999 Protocol on Water and Health to the Convention on the Protection and Use of Transboundary Watercourses and Lakes (London, 17 June 1999), UNTS 2331, 202, in force 4 August 2005 $6,32,168,303$

Protocol to Abate Acidification, Eutrophication and Ground-level Ozone (Gothenburg, 30 November 1999) 2319 UNTS 81, in force 17 May 2005 202

2000 Protocol on Biosafety to the Convention on Biological Diversity (Cartegena, 29 January 2000), 2226 UNTS 208, in force 11 September 2003

2001 Convention on Persistent Organic Pollutants (Stockholm, 22 May 2001), 40 ILM 532, in force 17 May 2004

International Treaty on Plant Genetic Resources for Food and Agriculture (Rome, 3 November 2001), in force 29 June 2004

2002 Association of South East Asian Nations, Agreement on Transboundary Haze Pollution (Kuala Lumpur, 10 June 2002), unreported, in force 2003 ...28, 227 ,

302

2003 Framework Convention for the Protection of the Marine Environment of the Caspian Sea (Tehran, 4 November 2003), unreported, in force 12 August 2006 $9,28,285,302$ Protocol on Pollutant Release and Transfer Registers to the Convention on Access to Information, Public Participation in Decision-Making and Access to Justice in Environmental Matters (Kiev, 21 May 2003), unreported, in force 8 October 2009 $18,62,254,303$ 
Protocol on Strategic Environmental Assessment to the Convention on Environmental Impact Assessment in a Transboundary Context (Kiev, 21 May 2003) unreported, in force 11 July 2010 ....................6, 31, 60, 106, 301 Protocol on Civil Liability and Compensation for Damage Caused by the Transboundary Effects of Industrial Accidents on Transboundary Waters (Kiev, 21 May 2003) unreported, not in force $18,138,168,305$

2006 Framework Convention on Environmental Protection for Sustainable Development in Central Asia (Ashgabat, 22 November 2006) TRE-143806, not in force. Accessed 20 November 2014 at http://www.ecolex.org/ server2.php/libcat/docs/TRE/Full/En/TRE-143806.pdf ....

2013 Minamata Convention on Mercury (Kumamoto, 10 October 2013) unreported, not in force

\section{European Union Legislation}

1985 Directive 85/337/EEC of 27 June 1985 on the assessment of the effects of certain public and private projects on the environment, [1985] OJ L175/40, 40-48

2000 Directive 2000/60/EC of the European Parliament and of the Council of 23 October 2000 establishing a framework for Community action in the field of water policy, [2000] OJ L327/1, 1-73

2001 Directive 2001/42/EC of the European Parliament and of the Council of 27 June 2001 on the assessment of the effects of certain plans and programmes on the environment, [2001] OJ L197/30, 30-37

2004 Directive 2004/35/CE of the European Parliament and of the Council of 21 April 2004 on environmental liability with regard to the prevention and remedying of environmental damage, [2004] OJ L143/56, 56-75

2006 Regulation (EC) No. 166/2006 of the European Parliament and of the Council of 18 January 2006 concerning the establishment of a European Pollutant Release and Transfer Register, [2006] OJ L33/1, 1-17

2012 Directive 2012/18/EU of the European Parliament and of the Council of 4 July 2012 on the control of major-accident hazards involving dangerous substances, amending and subsequently repealing Council Directive 96/ 82/EC Text with EEA relevance, [2012] OJ L197/1, 1-37 